\title{
The impact of globalization on the business position of European Union
}

\author{
Zuzana Rosnerova ${ }^{1, a^{*}}$, Dagmar Hraskova ${ }^{2, \mathrm{~b}}$ \\ ${ }^{1}$ University of Zilina, Faculty of Operation and Economics of Transport and Communications, \\ Department of Economics, Univerzitna 1, 01026 Zilina, Slovak Republic \\ ${ }^{2}$ University of Zilina, Faculty of Operation and Economics of Transport and Communications, \\ Department of Economics, Univerzitna 1, 01026 Zilina, Slovak Republic \\ azuzana.rosnerova@ @pedas.uniza.sk, bdagmar.hraskova@ fpedas.uniza.sk \\ *Corresponding author
}

\begin{abstract}
We are meeting with the term globalization for many years. The globalization process sets in motion goods, services, financial flows, information, through globalization come to the mobility of people, the workforce and globalization is also a power drive to move the whole world. This paper deals with the contribution of globalization to the EU market. The aim is to find out to what extent EU countries are involved in world trade. It also points to the position of the World Trade Organization, which is the only organization connecting the countries of the world, with the aim strengthening of world trade and ensuring its liberalization. We assume that the EU as the largest integration group in the world will play an important role in world trade and that EU countries will be among the top 10 world players. The document contains an analysis of the EU's position in world trade. The methodology used is based on comparing the export shares of the top 10 world trade countries and assessing how the countries of the EU positioned on the scale in 2018. The discussion deals with assessing the findings and estimating the situation in the future.
\end{abstract}

\section{Introduction}

Globalization can be defined as a process of expanding, deepening and accelerating the movement of goods, services, people or ideas between countries of the world. It is a longterm process in terms of time. The elements of ongoing globalization date several centuries back, when people tried to discover new places and exchange goods. As humanity itself continues to progress, there have been huge changes in the exchange of goods. Initially, goods were exchanged for goods more or less regionally, today goods are shipped around the world, mainly due to scientific and technical progress, infrastructure development, communication equipment development.

Today, the products are not only produced by certain countries, but production takes place around the world. Countries can produce goods for less money and specialize in producing products, for which the country has the best conditions. This way there to process of using economies of scale a in global markets. 
As far as market trading is concerned, the basic rule is that market players, but also the market itself, behave rationally, in such a way as to maximize their benefits as much as possible. In the event that a market participant has made an incorrect decision, this will not effect on market prices. [1]

To be successful on the market, an enterprise must pursue one important fact. As a market player, an enterprise must monitor its current financial situation and think of a situation such as bankruptcy. Among the best known models that can be applied in the context of bankruptcy prediction is the Altman model, which assesses the financial health of a company. According to this model it is possible to determine its status and estimate the market position in the future. [2]

In the area of trade policy, banking is also linked to globalization, which has a significant impact on the financial functioning of companies that, within their financial capacity, can also link to foreign trade. Banks are a very important entity for businesses and play a deciding role in the national economies of the individual countries of the world. [3]

An integral part of any economy is the issue of inflation. Since the state of the national economy reflects business activity, businesses must also focus on inflation and decide what type of strategy they will choose in their business. [4]

The current process of globalization is marked by the significant development of communication and information technologies, the use of the Internet, the internationalization of the media and the significant economic growth of Asian countries (especially China, India and South Korea).

The first signs of globalization date back to approximately 1860-1914. During this period, transport has developed and improved, mainly due to the migratory wave of people, the growth of international trade and the world commodity market. The biggest great power in the world at that time was Great Britain, but this wave ended in a result of the First World War.

Another wave of globalization occurred after World War II, between 1950 and 1980, when countries felt the need to solve global problems. Globalization was hampered by the Cold War and the disputes between the Western and Eastern blocs. The world power at the time was the United States of America, mainly because of the Bretton Woods Agreement, which set the system of fixed currencies of the main currencies tied to the dollar as the world currency. [5]

The paper focuses on the impact of globalization on trade in EU countries. The paper also depicts the position of the World Trade Organization, which alone governs the rules of world trade. We assume that these rules also greatly affect the European Union's trade market and that in the global market the EU will be an important player with a decisive share in world exports. The aim of the paper is to appreciate the representation of EU countries in world export.

The following part of the paper is focused on the position of the World Trade Organization and its operation. We also assess the advantages and disadvantages of ongoing globalization. The third part is devoted to world exports in 2018 represented by the top 10 countries of the world. We will come out comparing the top 10 exporters' rankings with the emphasis on EU countries. The last part of the paper is oriented on the assessment of the findings and discussion.

\section{Theoretical aspects of position WTO in world trade}

International organizations also play an important role in trade. These include the World Trade Organization (WTO). The WTO is the only international organization to regulate trade between countries, trade liberalization and international trade between countries. 
Currently, the WTO covers trade rules for 164 of member countries. The WTO ensures that international trade is easy and at the same time it must be predictable and free to the greatest extent possible. [6]

\subsection{Development of multilateral trading system}

The first roofing of the multilateral trading system appears more than 70 years ago under the General Agreement on Tariffs and Trade (GATT) in 1948. The multilateral trading system, by its name, suggests it is the conclusion of trade agreements, where such an agreement is approached by several countries at the same time.

This means that countries conclude more multilateral agreements with each other, as opposed to bilateral agreements. This means that countries conclude multilateral agreements with each other, as opposed to bilateral agreements. The authors Kohl, Brakman and Garretsen also point to differences between trade agreements. [7]

The GATT was created as a result of the post-war situation in the world, when the US had surpluses of industrial goods and it was necessary to look for markets for these goods. GATT regulated trade rules and tariff reductions and on the basis of these conditions, countries negotiated trade agreements.

The main essence of the GATT was the gradual removal of barriers to free trade reducing tariffs and limiting the use of import quotas by the Parties. The creation of a multilateral trading system has led to a positive improvement in the trading situation in the world. Total trade in 2002 was 22 times higher than total trade in 1950.

GATT has been linked to addressing business terms through conferences. At these conferences, the terms of the trading system were discussed, resulting in tariff reductions and thus helped to develop international trade and strengthen international cooperation.

Establishment of the World Trade Organization on 1 January 1995 is a successor to the GATT. [8]

\subsection{Activities, objectives, principles and structure of the WTO}

The WTO Agreement was signed in Marrakesh on 15 July 1994 and was established as a full organization on 1 January 1995, based in Geneva. The WTO, together with the World Bank and the International Monetary Fund (IMF), are the three pillars of the world economy.

\section{The primary role of the WTO is:}

- develop international trade in goods, services and intellectual property,

- settling trade disputes between member states. Transnational criminal law has led to the creation of law enforcement from a global perspective. [10 [11]

- to monitor the trade policies of individual countries.

It also ensures cooperation with other international organizations and supports the progress of developing countries through technical assistance or training.

\section{Among the objectives of the WTO we can include:}

- liberalization of trade policy (in particular tariff reductions and removal of trade barriers). Looking at the Duina's and Smith's publication, they are of the opinion that trade liberalization has never had cultural or symbolic content.

- raising living standards,

- decline in unemployment,

- optimal use of natural resources in accordance with the rules of sustainable development, 
- environmental protection. [12]

\section{WTO principles}

In order to liberalize trade rules, the principles underlying the functioning of the organization must also be respected. These principles include the principle of nondiscrimination, which assumes that all members are treated equally.

Another principle is the principle of national treatment, which is based on the idea that market access does not distinguish between domestic or foreign suppliers.

Another is the principle of predictability, stability and transparency, whereby trading partners can rely on the legally binding and invariable trading rules in the long term.

Last but not least, the development principle, which assumes support and development provided to less developed or developing countries, remains. [5]

\section{WTO structure}

The WTO structure is based primarily on the WTO Agreement. Other very important agreements are:

- the GATT-Agreement covers trade in non-agricultural and economic goods,

- GATS - covers the area of trade in services,

- TRIPS Agreement - regulates intellectual property rights issues. [5]

\subsection{Advantages and disadvantages of globalization for world trade}

Globalization also brings advantages and advantages. Benefits include:

- internationalization of the market: opening up borders has improved market access.

- information technologies: which affect the time and space barriers. Today it posiible to transmit via the Internet.

- trade liberalization: has caused world trade to grow greatly.

- competition: companies competing improve the quality of services and services offered. The consumer has a wide supply of products on the market. [13] [14]

The disadvantages include:

- energy crisis: humanity is gradually depleting available resources, and these are becoming increasingly scarce.

- migration crisis: migračná kríza je tiež považovaná za vel'ký nedostatok a jej problematikou sa vo svojej publikácii zaoberajú aj autori Hooghe and Marks

- unemployment: scientific and technological progress and the automation of production pose threats to people's employment, as artificial intelligence is now replacing the workforce. the issue of unemployment is also discussed by Greblikaite, Sroka, Grants in their publication dealing with the issue of social enterprises.

- position of monopolies: it is a particular threat to the financial markets, where large corporations are trying to speculate on the financial market.

- economic differences between countries [15] [16] [17]

\section{Practical part - the situation in 2018 on the world export market}

The level of economic growth depends on international trade. This is his driving force. Most of countries export their production or services to other countries. Export is very 
important, because it directly affects economic growth, living standard of the economy and employment.

In 2018, it ranked among the 10 largest world exporters: China, the USA, Germany, Japan, South Korea, the Netherlands, Hong Kong, France, Italy and the United Kingdom.

China dominated on the world market in 2018, reaching USD 2.4 trillion in exports. China ranks among the world's largest population with more than 1.3 billion inhabitants. The commodities China most exports are: computers, electrical machinery, telecommunications equipment, clothing, furniture or textiles. Most of this production is exported to the USA (19\%), Hong Kong (12.4\%), Japan (6\%) and South Korea (4.5\%).

The second largest exporter was the United States, which in 2018 achieved exports of $\$ 1.6$ trillion. They export mainly organic chemicals, motor vehicle parts, cars, airplanes, computers, medicines and agricultural products. Their sales markets include Canada (18.3\%), Mexico (15.7\%), China (8.4\%) and Japan (4.4\%).

The third position was taken by Germany with exports of 2018 USD 1.5 trillion. Germany ranks among the strongest economies within the Eurozone. It exports mainly machinery, motor vehicles, chemicals, pharmaceutical products and exports mainly to the USA (8.8\%), France (5.1\%), Australia (4.9\%), Poland (4.7\%) or Switzerland (4\%).

Japan became the world's fourth largest exporter with exports of $\$ 738$ billion in 2018. It exports mainly motor vehicles, iron and steel products, automotive components, power generation machines and plastics. Japan's major trading partners are the USA (19.4\%), South Korea (7.6\%), Hong Kong (5.1\%) and Thailand (4.2\%).

South Korea took fifth place in world trade, reaching USD 605 billion in exports in 2018. It exports mainly semiconductors, spare parts for cars, boats, wireless communication devices, electronics or computers. The main trading partners are China $(25.1 \%)$, the USA (12.2\%), Vietnam (8.2\%), Japan (4.7\%) and Hong Kong (6.9\%).

The sixth strongest exporter in the world in 2018 was Netherlands US \$ 585.6 billion. Food, livestock, chemicals, machinery and transport equipment are mainly exported. The most important trading partners are Germany (24.2\%), Belgium (10.7\%), the United Kingdom (8.8\%), France (8.8\%) and Italy (4.2\%).

Hong Kong is in seventh place with an export volume of USD 569 billion. This relatively small autonomous territory is a very important link in global trade. Exports consist of goods such as textiles, electrical machinery and equipment, toys, watches. In terms of exports, China (54.1\%) and the US (7.7\%) are key trading partners for Hong Kong.

France ranked eighth in exports in 2018 with a value of $\$ 568.4$ billion. The main export commodities include aircraft, chemicals, plastics, pharmaceutical products. Major markets for France are Germany $(14.8 \%)$, Spain $(7.7 \%)$, Italy $(7.5 \%)$, the USA $(7.2 \%)$, Belgium (7\%) and the United Kingdom (6.7\%). \%).

Italy is ninth in global exports, with an export value of \$ 543.4 billion. The country exports mainly motor vehicles, machinery and equipment, food, beverages, minerals, tobacco or textiles. Important sales markets are Germany (12.5\%), France (10.3\%), USA (9\%), Spain (5.2\%), United Kingdom (5.2\%) and Switzerland (4.6\%) .

The tenth ranked was the United Kingdom with an export volume of $\$ 487$ billion. Exports consist of fuels, chemicals, food, beverages and tobacco. The leading trading partners include the USA $(13.2 \%)$, Germany $(10.5 \%)$, France $(7.4 \%)$, the Netherlands (6.2\%), Ireland (5.6\%), China 4.6\%) and Switzerland (4.5\%). [18] [19] 


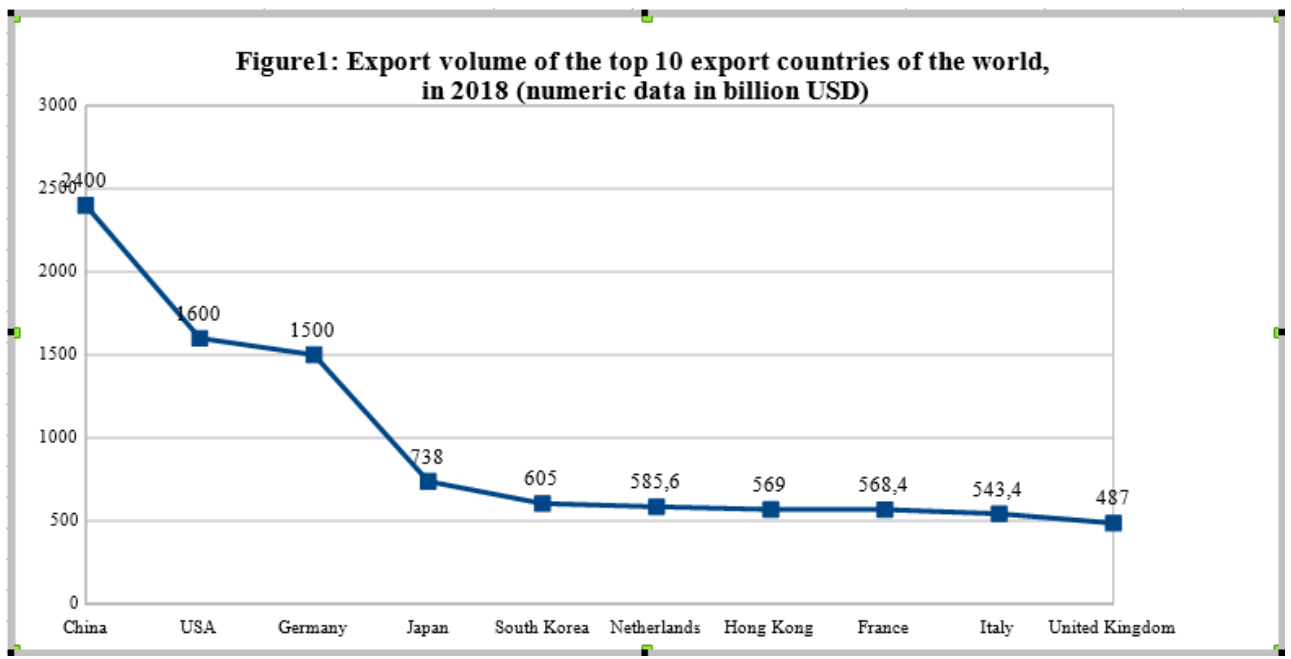

Fig. 1. Export volume of the top 10 export countries of the world, in 2018 (numeric data in billion USD)

The chart shows the ranking of the countries evaluated. The first three places were occupied by China, USA and Germany. So in the first trinity figure the one of the EU's countries. Other countries that are members of the EU and are among the top 10 exporters are the Netherlands, France, Italy and the United Kingdom, which is currently still one of the EU members.

\section{Discussion and conclusion}

Based on the findings of a comparison of the world's top 10 countries in world exports, we can conclude that the EU is clearly a strong global player in global trade. The countries, that of EU figuring the top 10 exporters in the world in 2018: Germany, the Netherlands, France, Italy and the United Kingdom. This means that up to 5 of the world's leading exporters are EU countries. For this reason, it is clear that the EU is a major exporter of the world. Germany even occupied an excellent third position. The United Kingdom, which is still a Member State of the EU, is now in its tenth position negotiating on Brexit. The question is how the situation will evolve after the United Kingdom leaves the EU. Thus, the EU will not be a grouping of 28 Member States, but only 27. If the United Kingdom leaves the integration grouping, this will undoubtedly also have an impact on the business performance for EU territory. In the future survey, we could address the issue of losing an important EU player for its trade and position in the global market at a time when the UK is no longer an EU Member State.

\section{References}

1. K. Valaskova, V. Bartosova, P. Kubala, Behavioural Aspects of the Financial Decision-Making. Organizacija, 52, 22-32 (2019)

2. B. Gavurova, M. Packova, M. Misankova, L. Smrcka, Predictive potential and risks of selected bankruptcy prediction models in the Slovak business environment. Journal of Business Economics and Management, 18, 1156-1173 (2017)

3. A.P. Balcerzak, T. Kliestik, D. Streimikiene, L. Smrcka, Non-Parametric Approach to Measuring the Efficiency of Banking Sectors in European Union Countries. Acta Polytechnica Hungarica, 14, 51-70 (2018) 
4. P. Kral, K. Janoskova, Condition Of Acceptability Of Project Risk In Management Of The Project Portfolio, In: 15th International Scientific Conference on Globalization and its Socio-Economic Consequences, Rajecke Teplice, 345-352 (2015)

5. Z. Rosnerova, (2014). Aktualny stav a vyhlady obchodnej politiky EU vo vztahu k WTO, EDIS, 47 (2014)

6. C. Hofmann, A. Osnago, M. Ruta, The Content of Preferential Trade Agreements, World Trade Review, 18, 365-398 (2019)

7. T. Kohl, S. Brakman, H. Garretsen, Do Trade Agreements Stimulate International Trade Differently? Evidence from 296 Trade Agreements, World Economy, 39, 97-131 (2019)

8. J.Y. Joo, Restructuring GATT Balance-of-Payments Safeguard in the WTO System. Journal of World Trade, 53, 589-623 (2019)

9. A.M. Countryman, B.G. Narayanan, Price volatility, tariff structure and the special safeguard mechanism, Economic Modelling, 64, 399-408 (2017)

10. S. Garcia, C.R. German, P.S. Bernardo, Expansion of Global Rule by Law Enforcement: Colombia's Extradition Experience, 1999-2017, Contemporary Readings in Law and Social Justice, 10, 104-129 (2018)

11. H.W. Lee, Legalization and dispute settlement benefits: The case of the GATT/WTO, Review of International Organizations, 14, 479-509 (2019)

12. F. Duina, E. Smith, Affirming Europe with trade: deal negotiations and the making of a political identity. Comparative European Politics, 17, 499-511 (2019)

13. M.Y.P. Peng, K.H. Lin, International networking in dynamic internationalization capability: the moderating role of absorptive capacity. Total Quality Management \& Business Excellence. (2019)

14. G. Berlingieri, H. Breinlich, S. Dhingra, The impact of trade agreements on consumer welfare-evidence from the EU common external trade policy, Journal of the European Economic Association, 16, 1881-1928 (2018)

15. L. Hooghe, G. Marks, Cleavage theory meets Europe's crises: Lipset, Rokkan, and the transnational cleavage, Journal of European Public Policy, 25 (2018)

16. J. Fan, Internal Geography, Labor Mobility, and the Distributional Impacts of Trade. American Economic Journal-Macroeconomics, 11, 252-288 (2019)

17. J. Greblikaite, W. Sroka, J. Grants, Development of Social Entrepreneurship in European Union: Policy and Situation of Lithuania and Poland, Transformations in Business \& Economics, 14, 376-369 (2015)

18. WTO, [online]. Available at: < https://www.wto.org/english/news_e/pres19_e/pr8 37_e.htm> (2019) 